\title{
PRICE FORMATION IN TRADE COMPANIES
}

\author{
STOJKOVIĆ Milica ${ }^{1}$, JEREMIJEV Violeta ${ }^{2}$ \\ ${ }^{1}$ Faculty of Business Economics and Entrepreneurship, Belgrade (SERBIA) \\ ${ }^{2}$ Stefan logistics, Nis (SERBIA) \\ E-mails: milica.stojkovic@vspep.edu.rs
}

\begin{abstract}
A trading company should be viewed as a complex system of organization that operates in a dynamic and multi-conditioned business environment, with the aim of creating economic value for its owners and for the consumers themselves. Constant changes in the environment determine the opportunities, dangers and limitations for trading companies. Therefore, it is necessary for a trading company to precisely define and at the same time realize a number of goals that are mutually compatible and integrated. Since the company is established for the purpose of achieving certain economic and other goals, all procedures, activities and activities of the company and all holders of functions in the process of its business are goaloriented and oriented. From the point of view of creating the sales policy of trade companies, the margin is of special importance, as the difference in the price that the trade adds to the purchase price in order to cover its costs. Regardless of whether the margin is administratively determined or is formed freely, sales prices are different. This means that, in the system of free margin formation, trade independently determines the difference in price, starting from business costs, planned profit and market conditions.
\end{abstract}

Keywords: trade, price, company, business, margin

JEL: E30

DOI: 10.5937/intrev2103066S

UDC: 338.534

COBISS.SR-ID 55093001 


\section{INTRODUCTION}

Trade companies as well as companies from other areas of business must take into account the achieved productivity; the financial position of the trade; financial structure; trade liquidity; property and capital structures; economy, profitability and turnover in trade, trade margin and investment[1]. Trade is an economic activity that deals with the purchase of goods for sale and making a profit. It is a "bridge" that connects producers and consumers. The financial reason for the existence of trade companies is earnings. Trading companies must balance the price and volume of sales (demand) of products if they want to achieve maximum profit and effective inventory management. In a trading environment, the price depends on parameters such as: the importance of the product to the manufacturer; consumer purchasing power (income); relative product price; availability of acceptable alternatives; customer loyalty; competition; quality perception[2]. The consumer is of key importance for the decision made by the trader about the price of the goods. The formation of the price of goods is therefore influenced by: the consumer, the trader (trading company) and its needs, as well as competition.

\section{CONSUMER VALUATION, TRADER EARNINGS AND COMPETITION}

Value assessment is a process of comparing prices and quality where the consumer checks whether the price of the product is reflected in its quality. If the price and quality seem to be uniform, the consumer believes that the value is appropriate. However, real and perceived quality are not one and the same, so the relationship between price and quality does not have to be linear. If the trader convinces the buyer that the product is of sufficient quality, the buyer will buy the product even though the price is high or increased (the goods have become more expensive). If the consumer has limited knowledge of the prices that competitors have, the benchmark does not exist, so now the valuation becomes very subjective, unless some tangible factors cannot be determined (such as ingredients or quality of workmanship). Customers compare prices before and during the purchase, either within the store or between different stores.

The main purpose of the company's existence, perpetuated in the Law on Enterprises, is to generate profit. A trading company is a company and its goal is to create as much profit as possible for its owners or shareholders. The profit of a trading company is affected, of course, by the price at which it sells goods, but also by its purchase price, as well as operating costs and turnover. Without competition, the trader could set any price. Since competition exists, one must take into account the purchase prices, trade margins that are added to them and the formed sales prices.

\section{SALES PRICE CALCULATION IN TRADING COMPANIES}

Management of trade costs and formation of sales prices is one of the complex and sensitive issues in the field of business policy of trade operators. The interests of producers, trade and consumers, as well as society as a whole, are affected by the question of prices. The company is interested in price stability because it is the basis of market stability. Consumers, however, are interested in selling prices as low as possible, while trade, in the role of seller, is interested in keeping prices as high as possible. Sales prices affect production and sales at the same time, and thus trade costs. Therefore, the policy of sales prices in trade cannot be conducted partially from today to tomorrow. Trade in sales price policy should resolve the conflicting interests of participants in trade. Prices should be attractive to consumers, competitive with the prices of the range of related suppliers and high enough to ensure profits and profitable trade operations [3]. The elements of the sales price calculation are: invoice price, dependent costs, purchase price $(1+2)$, price difference, sales price without VAT $(3+4)$, VAT, Sales price with VAT $(5+6)$. [4]

With a strategic approach through prices, and also through other elements, one must always take into account that in modern turbulent business conditions, every stay at one level represents stagnation and inevitably leads to failure. Modern conditions require the necessity of constant change of assortment, design, expansion of additional services to customers, raising the quality of products, relations with customers and suppliers, etc. Price is a quantitative expression of the value of the product, ie. the amount of money that the customer pays as the equivalent of the purchased product. The impact of prices on corporate profits is direct, so price is the most dynamic marketing instrument. Traders generally face three 
basic problems when forming prices: how to determine the first prices for a product, how to modify the price in time and space, how to initiate and how to react to price changes.

Being cheaper does not necessarily mean "being more competitive", ie lower prices than the competition are not a sufficient precondition for success. The importance of competition is traditionally emphasized due to the elasticity of demand, as well as the disproportion between the needs and requirements of consumers and their ability to pay [5]. The effects of price competition will not achieve the desired effect, if there are no adequate non-price elements of the offer, such as: product quality, design, product flexibility, after-sales service, delivery times and other forms of marketing support. As a rule, competitive price is important for simple products and in less developed countries, while the demand for expensive and sophisticated product variants is higher in developed markets.

\section{PRICING STRATEGIES}

Pricing strategies are ways to achieve the goals of price positioning. The main goals are: to cover costs and make money, to achieve, maintain and expand the desired market share, to respond to the challenges of competition and to achieve economic strength and market influence in order to achieve growth and development of the company. When the goals that the price should achieve are set, the trader chooses a strategy that will help him achieve those goals. Prices can be set below, at, or above market levels. Prices are affected by all major groups of stakeholders in the trade process: producers, consumers, competition, the trader himself, legislation (in the form of competition protection and price fixing). The four basic pricing strategies focus on the relationship between price and quality and it is good to look at them in the form of a $2 \times 2$ matrix[6]:

\begin{tabular}{|c|c|c|}
\hline \multirow{3}{*}{ 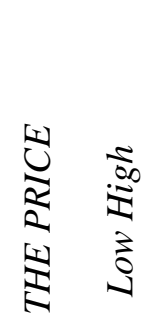 } & \multicolumn{2}{|c|}{$\begin{array}{l}\text { QUALITY } \\
\text { Low High }\end{array}$} \\
\hline & $\begin{array}{c}\text { "Slashing product } \\
\text { prices" }\end{array}$ & Premium \\
\hline & Basic & Penetration \\
\hline
\end{tabular}

The consumer can perceive the price as low or high, and the quality as low or high. The trader should choose which aspect of quality is important for the consumer: product quality, product brand, store image, etc. This is, of course, about perceived rather than actual quality. A slash running along the diagonal of the matrix indicates products where the price-quality ratio is the same. Squares where both price and quality are matched (both high-premium offer or both low-base offer) are seen as "fair" squares where the customer gets as much value as he paid. When a product provides more quality than the consumer has paid for, the trader applies a strategy (market penetration and market share-to-profit). A quadrant in which low-quality goods are sold at a high price is popularly called "peeling" because the consumer did not get value for his money. Luxury products and modern clothes (fashion) are in the premium quadrant or in "slashing product prices". Discounts are in the base quadrant. In addition to these four "generic" models, two specific models are modern versions of the existing ones, and they are: low price every day and high price low.

Traders who apply a strategy of low prices on a daily basis position their stable price somewhere between the regular price of competition (market price) and the promotional price (sale). Access is therefore a low price every day, but not the lowest. The advantages of the daily low price model are: prices are stable throughout the year, it usually turns out that this is the lowest price (if the average for the whole year), better control of sales forecast, better financial performance because there are no oscillations due to frequent sales, more efficient system, lower marketing costs (no sale and promotion of shares), no "price installment".

The disadvantages of daily low prices are: margins are lower, but when averaged, they may actually be better than regulatory retailers that have both sales and action "waves", lower profits, hard to endure, as a good portion of products are national brands, consumers he can experience such a retailer, with low prices every day, as someone with low quality goods, because, for the sake of the world, prices are low; equalization with discount. Small and specialized retailers rarely decide for a low-cost strategy on a daily basis. 
A high / low price retailer applies a hybrid strategy between a regular retailer and a retailer with low prices on a daily basis. Regular (regular) prices are above daily low, but are often, promotional (sale of individual items) below daily low prices. The first is a method that retailers love and often apply. When applied correctly. The high / low method has all the advantages of premium prices (perhaps even encroaching on "slashing product prices") throughout the year, with "penetration" prices during sales and discounts. The method achieves good results if the scheduling periods are short enough. In a way, customers pay higher prices throughout the year, except at the time of sales when they enjoy low prices on the entire range. The margin is usually good, while the perception of consumer value is not damaged because they are aware of the good deals that the selling prices have compared to the regular ones.

The advantages of the high / low method are:

- The same range is attractive to a wider range of consumers

- for those with a "deeper pocket" who are less price sensitive, the purchase is perceived as the purchase of quality products, regardless of the price,

- The first sales attract price-sensitive consumers who would not normally buy,

- promotions and sales achieve excitement and usually positive effects,

- The perception of value is intact, if sales are not frequent.

The disadvantages of the high / low price strategy are:

- There is a danger that the retail store will "slip" and, for the sake of better sales volumes, it will extend the time of sales. Then the consumer begins to believe that regular prices are inflated and that it is better to wait for the sale, which will soon the margin may decrease due to the volume of products sold at a discount.

- Tactical pricing of individual products on a daily basis is part of price implementation. Tactics fall into two broad groups:

a) differential price policy (according to geographical area, according to product promotion or before a competitor),

b) a price level that sets a point of comparison between alternative offers (in the minds of consumers, related to the category or sale of multiple packages with a larger number of individual items).

It is not uncommon for the price of the same product to vary depending on the geographical area. Price variation occurs in the midst of several factors:

- Relative location can affect the cost of shipping goods,

- market factors such as the presence or absence of competitors,

- macro and environmental factors (higher or lower living standard of the population, exchange rate variation, influence of government and local self-government, etc.),

- strategies of retailers that in certain, what they see in strategic markets have lower prices, and in less important more and more.

Promotional pricing contains a whole range of creative marketing concepts: multiple product packages, packaged products, products on sale, "introductory" price of a new product on the market, leader line, events and seasonal prices, Matching offer, rests or "everything for 100 dinars". Setting prices in accordance with the prices of competitors - here the parameters of comparison come to the fore, such as products that are compared and products of known value. It is interesting from the position of a trader that these two groups of products contribute very little to the turnover of the store. The retailer will not lose much if he discounts these products, but the competition will "break the trump card" because consumers will stop making their comparisons - they have found a price leader. Psychological setting of prices is a relative novelty in Serbia that the prices are not rounded off but put "just below" at 249 dinars or 24.95 dinars. In America, this practice has been applied for more than 100 years. The price of 799 indicates a discounted price while the price of 1500 dinars indicates that quality is more important than price. Over time, consumers learn that prices that end with "9" or "99" mean a discount, and then begin to believe that regular prices that end with nine are also discounted and therefore good value for money.

Setting prices according to the category of requirements sets specific and relative prices for the entire population of categories. If a product category contains a whole range of prices that are difficult to compare, it will be difficult for the consumer to compare the value. And when the consumer is confused - he doesn't buy. An equal price ratio was seen as more acceptable than an unequal one. The price of a 
unit of measure - the trader shows that the price of a package of $3 \mathrm{~kg}$ of detergent is 549 dinars, and in parentheses he says that it is 183 dinars per kilogram. This helps the customer to compare the prices of different products that are packaged differently. Most countries legally regulate such price expressions for the sake of full price transparency and consumer protection.

The attractiveness of low prices should not be underestimated. Buyers are always looking to buy something at a "good" price or what looks like a "good market". There is a link between the price level as perceived by the buyer and the value that purchase has for the buyer. But price and value are not one and the same. Managing customer expectations is the essence of people's marketing business. The buyer will probably be satisfied if he estimates that the value of the benefit he received from the purchase is greater than the "sacrifice" or the cost he paid to own it.

\section{CONCLUSION}

In the system of free margin formation, trade independently determines the difference in price, starting from business costs, planned profit and market conditions. In such conditions, the store has the opportunity to combine the price policy with other instruments of the marketing mix. Despite frequent warnings that the free formation of margins can have negative consequences on the consumer budget and the economy as a whole, price differentiation in trade is economically desirable. Timely price differentiation by lowering margins allows trade to get rid of non-current goods. Geographical differentiation of prices through margins arises as a consequence of differences in costs, or due to market imperfections. Differentiation of prices through margins is possible in both wholesale and retail trade, and it allows trade to adjust prices to market conditions.

One of the most difficult tasks in the transition of the economy of the Republic of Serbia certainly refers to the construction of a modern market and modern trade. Trade, and especially retail, has a crucial role to play in creating market conditions for business.

\section{REFERENCES}

[1] Lovreta, S., (2008), Strategija i politika razvoja trgovine Republike Srbije, Ministarstvo trgovine i usluga, Ekonomski fakuletet, Beograd

[2] Golijanin, D., (2010), Marketing u trgovini, Univerzitet Singidunum, Beograd

[3] Ćuzović, S., (2009), Trgovina :Principi, struktura, razvoj, Ekonomski fakultet, Niš

[4] Krstić, J., Jezdimirović, J., Đukić, T., (2010), Finansijsko računovodstvo, Ekonomski fakultet, Ni

[5] Rakita, B., (2003), Međunarodni marketing, Ekonomski fakultet, Beograd

[6] Golijanin, D., (2011), Marketing u trgovini, Beograd

\section{Article history:}

Received 15 November 2021

Accepted 17 December 2021 